\title{
Widespread Molecular Alterations Present in Stage I Non-Small Cell Lung Carcinoma Fail to Predict Tumor Recurrence
}

Fabien K. Baksh, M.B.B.S., Sanja Dacic, M.D., Ph.D., Sydney D. Finkelstein, M.D., Patricia A. Swalsky, B.Sc., Siva Raja, B.Sc., Eizaburo Sasatomi, M.D., James D. Luketich, M.D., Hiran C. Fernando, M.D., Samuel A. Yousem, M.D.

Departments of Pathology (FKB, SD, SDF, PAS, ES, SAY) and Surgery (SR, JDL, HCF), University of Pittsburgh Medical Center, Presbyterian University Hospital, Pittsburgh, Pennsylvania

Stage I non-small cell carcinoma (NSCLC) of the lung is typically treated with surgery alone, but with a 30 to $40 \%$ recurrence rate. Prognostic factors to stratify these patients into high- and low-risk groups would be of significant clinical value, but published data are conflicting. We studied 39 Stage I NSCLC treated with resection alone, followed for a minimum of 5 years, and divided into recurrent (RC) and non-recurrent (NRC) groups ( $n=12$ and 27, respectively). Allelic imbalance (loss of heterozygosity, LOH) involving genomic regions containing L-myc (1p32), hOGG1 (3p26), APC/MCC (5q21), c-fms (5q33.3), p53 (17p13), and DCC (18q21), and point mutational change in K-ras-2 (12p12) were studied by PCR-based microsatellite analysis and DNA sequencing. Mutations in k-ras-2 were seen in $25 \%$ and $19 \%$ of RC and NRC tumors, respectively, most frequently in adenocarcinomas. LOH in the RC and NRC respectively were $50 \%$ and $37 \%$ for L-myc, $60 \%$ and $33 \%$ for hOGG1, $60 \%$ and $50 \%$ for APC, $38 \%$ and $35 \%$ for $\mathrm{c}-\mathrm{fms}, \mathbf{7 8 \%}$ and $\mathbf{7 5 \%}$ for $\mathrm{p} 53$, and $17 \%$ and $45 \%$ for DCC. No statistical significance was seen comparing any of the allelic alterations with recurrence. LOH for hOGG1 and L-myc were more commonly seen in squamous cell carcinomas. Stage I NSCLC are genetically heterogeneous with respect to mutation acquisition. The approach of investigating a panel of genes for alterations can be applied to any given tumor type, and provides information on patterns of mutations/

Copyright @ 2003 by The United States and Canadian Academy of Pathology, Inc.

VOL. 16, NO. 1, P. 28, 2003 Printed in the U.S.A.

Date of acceptance: August 27, 2002.

Address reprint requests to: Sydney D. Finkelstein, M.D., Department of Pathology-PUH-A610.2, University of Pittsburgh Medical Center, 200 Lothrop Street, Pittsburgh, PA 15213; fax: 412-647-2358; e-mail: finkelsteinsd@msx.upmc.edu.

DOI: 10.1097/01.MP.0000044621.08865.C4
LOH that can help us better understand the molecular biology of tumorigenesis.

KEY WORDS: Loss of heterozygosity, Non-small cell lung carcinoma, Prognosis.

Mod Pathol 2003;16(1):28-34

Carcinoma of the lung is the second most frequent malignancy in men and women and the most frequent cause of cancer-related death in both sexes (31\% and $25 \%$, respectively) (1). Therapeutic intervention is based on a number of factors including the predicted outcome of the patient. The medical literature thus abounds with factors that affect prognosis, and one of the most important is stage of disease (2).

Stage I lung cancer includes the TNM-based T1N0M0 and T2N0M0 tumors (3) and is typically treated with surgical resection alone. However, approximately $50 \%$ of clinical Stage I and $30-40 \%$ of pathologic Stage I patients have disease recurrence and die after surgical resection $(4,5)$. These data suggest that a significant number of patients may benefit from adjuvant therapy at the time of diagnosis. Several studies have therefore focused attention on patients with Stage I disease in an attempt to identify prognostic factors that will stratify these patients into high- and low-risk groups for recurrence, with variable results. The various clinical and pathological factors identified include patient performance status, tumor size, histological subtype, mitotic rate, proliferative index, tumor angiogenesis, DNA ploidy studies, and blood group expression $(4,6-8)$.

Overexpression of p53 and c-erb by immunohistochemistry has been determined to be an indicator of poorer outcome (7). The issue of prognosis has also been addressed using molecular techniques aimed at identifying mutations, loss of heterozygosity $(\mathrm{LOH})$, microsatellite instability, or gain of func- 
tion in various genes, again with conflicting results $(9-19)$.

We examined the paraffin-embedded tissue of 39 pathologic Stage I non-small cell lung cancers (NSCLC), all followed for a minimum of 5 years, divided into recurrent (RC) and nonrecurrent (NRC) groups. A PCR-based technique was used to identify mutations in k-ras-2 and $\mathrm{LOH}$ using eight intragenic sites in six genes, namely 1p32 (L-myc), 3p26 (hOGG1), 5q21 (MCC/APC), 5q33.3 (c-fms), 17 p13 (p53), and 18q21 (DCC). We employed this panel approach to construct a typical molecular profile for Stage I NSCLC by identifying genes that are frequently affected in this disease. We then compared this profile with the histopathologic features of the tumors and analyzed the prognostic significance of our findings.

\section{MATERIALS AND METHODS}

The medical records archival system at the University of Pittsburgh Medical Center was searched for cases of completely resected NSCLC staged as pathologic Stage I. The clinical and histopathologic features of all cases were reviewed with respect to tumor size, histologic type (squamous cell carcinoma, large cell carcinoma, and adenocarcinoma), and presence or absence of pleural and angiolymphatic invasion. The pathologic stage of each tumor was determined as IA or IB according to the criteria of the American Joint Committee on Cancer (20). The patients were divided into RC and NRC groups based on a minimum of 5 years of clinical, radiologic, and when necessary, pathologic follow-up.

Four-micrometer-thick recut unstained histologic sections were microdissected under stereoscopic observation with the approval of the University of Pittsburgh Institutional Review Board. In each case a corresponding microdissected sample of normal lung was taken to be no larger in size than that of the corresponding tumor sample. Normal tissue samples were taken to establish informativeness status for intragenic microsatellites and/or single-nucleotide polymorphisms (SNP). Genotyping of microdissected normal tissue was also used to control for allelic imbalance in that all normal tissue samples at informative loci were expected to show balanced allelic content.

Microdissected tissue samples were treated with $50 \mu \mathrm{L}$ of Proteinase K (10 mg/mL) for 2 hours and boiled for 5 minutes to remove enzyme activity. Aliquots of each microdissected sample were PCR amplified in individual reactions for each polymorphic site using genomic-based oligonucleotide primers. In the case of microsatellite analysis, loss of heterozygosity (LOH) determination used electrophoresis in $6 \%$ polyacrylamide of PCR products labeled by radionucleotide incorporation (d-ATP). For SNP analysis of LOH, dideoxy chain termination sequencing was carried out according to manufacturer's instructions (Sequenase, United States Biochemical Corp, Cleveland, $\mathrm{OH}$ ), and the intensity relationship of the polymorphic band was used to determine allelic balance. Genotyping results were read from overnight exposed polyacrylamide gels.

The fractional allelic loss (FAL) in each tumor was defined as the total number of chromosomal loci with $\mathrm{LOH}$ divided by total number of informative loci examined (21).

The data were analyzed for statistical significance with SPSS 10.0.0 (Chicago, IL). The RC and the NRC were compared with one another using the $\chi^{2}$ test along with the Fisher's exact test. The continuous numeric data were evaluated using the $t$ test for independent samples.

\section{RESULTS}

Thirty-nine patients were identified and divided into recurrent $(n=12)$ and nonrecurrent $(n=27)$ groups with mean ages of 68.8 and 64.8 years, and mean tumor sizes of 3.5 and $3.2 \mathrm{~cm}$, respectively (Table 1). The male-to-female ratios were 7:5 and 17:10 in the respective groups. Histopathologic features of the NRC and RC Stage I NSCLC, with associated FAL, are summarized in Table 1 . Of the 27 NRC tumors, 7 were squamous cell carcinoma, 18 were adenocarcinomas, and 2 were large cell undifferentiated carcinoma. Pleural invasion was present in 2 cases, and angiolymphatic invasion was seen in

TABLE 1. Clinical and Histopathologic Features with Associated Fractional Allelic Loss (FAL) in Nonrecurrent (NRC) and Recurrent (RC) Stage I NSCLC

\begin{tabular}{|c|c|c|}
\hline Parameter & $\begin{array}{c}\text { NRC } \\
(n=27)\end{array}$ & $\begin{array}{c}\mathrm{RC} \\
(n=12)\end{array}$ \\
\hline \multicolumn{3}{|l|}{ Age (y) } \\
\hline Mean & 64.8 & 68.8 \\
\hline \multicolumn{3}{|l|}{ Gender, \% $(n)$} \\
\hline Male & $63(17)$ & $58(7)$ \\
\hline Female & $37(10)$ & $42(5)$ \\
\hline \multicolumn{3}{|l|}{ Stage, \% (FAL) } \\
\hline IA & $67(0.43)$ & $33(0.61)$ \\
\hline IB & $33(0.52)$ & $67(0.48)$ \\
\hline \multicolumn{3}{|c|}{ Histologic type, \% (FAL) } \\
\hline SCC & $26(0.56)$ & $42(0.67)$ \\
\hline $\mathrm{ADC}$ & $67(0.39)$ & $50(0.36)$ \\
\hline $\mathrm{LC}$ & $7(0.59)$ & $8(0.75)$ \\
\hline \multicolumn{3}{|c|}{ Pleural invasion, \% (FAL) } \\
\hline Present & $7(0.50)$ & $25(0.50)$ \\
\hline Absent & $93(0.46)$ & $75(0.58)$ \\
\hline \multicolumn{3}{|c|}{$\begin{array}{l}\text { Angiolymphatic invasion, } \\
\%(\mathrm{FAL})\end{array}$} \\
\hline Present & $11(0.58)$ & $33(0.41)$ \\
\hline Absent & $89(0.44)$ & $67(0.57)$ \\
\hline
\end{tabular}

NRC, nonrecurrent; RC, recurrent; SCC, squamous cell carcinoma; ADC, adenocarcinoma; LC, large cell undifferentiated carcinoma; FAL, fractional allelic loss. 
3 cases. Of 12 RC tumors, 5 were squamous cell carcinomas, 6 were adenocarcinoma, and 1 was a large cell undifferentiated carcinoma. Angiolymphatic invasion was present in 4 cases, and pleural invasion was seen in 3 cases. There was no significant difference between recurrent and nonrecurrent groups when analyzed against each of the histopathologic features studied, with only stage of disease approaching statistical significance $(P=$ $.053 ; \chi^{2}$ test). There was no statistically significant difference in FAL between RC and NRC in respect to histologic type or pleural or angiolymphatic invasion (Table 1).

The frequencies of $\mathrm{LOH}$ in NRC and RC at individual chromosomal loci and noninformative rates in the different histologic tumor types and Stages $1 \mathrm{~A}$ and $1 \mathrm{~B}$ are shown in Tables 2 and 3. The informativeness of the various markers varied from $36 \%$

TABLE 2. Frequencies of LOH (\%) at Individual Chromosomal Loci and K-Ras-2 Mutation in the Different Histologic Tumor Types in the Nonrecurrent (NRC) and Recurrent (RC) Stage I NSCLS

\begin{tabular}{|c|c|c|c|}
\hline $\begin{array}{l}\text { Chromosomal } \\
\text { Locus/Gene } \\
\text { Marker }\end{array}$ & $\begin{array}{l}\text { Histologic } \\
\text { Type }\end{array}$ & $\begin{array}{c}\text { NRC } \\
(N=27)\end{array}$ & $\begin{array}{c}\mathrm{RC} \\
(N=12)\end{array}$ \\
\hline \multirow[t]{3}{*}{ 1p32/L-myc } & SCC & $\begin{array}{c}57 \\
(\mathrm{NI}=0)\end{array}$ & $\begin{array}{c}60 \\
(\mathrm{NI}=0)\end{array}$ \\
\hline & $\mathrm{ADC}$ & $\begin{array}{c}28 \\
(\mathrm{NI}=0)\end{array}$ & $\begin{array}{c}17 \\
(\mathrm{NI}=0)\end{array}$ \\
\hline & LC & $\begin{array}{c}50 \\
(\mathrm{NI}=0)\end{array}$ & $\begin{array}{c}100 \\
(\mathrm{NI}=0)\end{array}$ \\
\hline \multirow[t]{3}{*}{ 3p26/hOGG1 } & SCC & $\begin{array}{c}100 \\
(\mathrm{NI}=86)\end{array}$ & $\begin{array}{c}100 \\
(\mathrm{NI}=80)\end{array}$ \\
\hline & $\mathrm{ADC}$ & $\begin{array}{c}40 \\
(\mathrm{NI}=72)\end{array}$ & $\begin{array}{c}50 \\
(\mathrm{NI}=33)\end{array}$ \\
\hline & LC & $\begin{array}{c}\text { NA } \\
(\mathrm{NI}=100)\end{array}$ & NA \\
\hline \multirow[t]{3}{*}{$\begin{array}{l}5 \mathrm{q} 21 / \mathrm{MCC} / \\
\mathrm{APC}\end{array}$} & SCC & $\begin{array}{c}67 \\
(\mathrm{NI}=57)\end{array}$ & $\begin{array}{c}100 \\
(\mathrm{NI}=60)\end{array}$ \\
\hline & $\mathrm{ADC}$ & $\begin{array}{c}40 \\
(\mathrm{NI}=44)\end{array}$ & $\begin{array}{c}0 \\
(\mathrm{NI}=67)\end{array}$ \\
\hline & LC & $\begin{array}{c}100 \\
(\mathrm{NI}=50)\end{array}$ & $\begin{array}{c}100 \\
(\mathrm{NI}=0)\end{array}$ \\
\hline \multirow[t]{3}{*}{$5 q 33.3 / \mathrm{c}-\mathrm{fms}$} & SCC & $\begin{array}{c}33 \\
(\mathrm{NI}=14)\end{array}$ & $\begin{array}{c}33 \\
(\mathrm{NI}=40)\end{array}$ \\
\hline & $\mathrm{ADC}$ & $\begin{array}{c}31 \\
(\mathrm{NI}=28)\end{array}$ & $\begin{array}{c}50 \\
(\mathrm{NI}=33)\end{array}$ \\
\hline & $\mathrm{LC}$ & $\begin{array}{c}0 \\
(\mathrm{NI}=50)\end{array}$ & $\begin{array}{c}0 \\
(\mathrm{NI}=0)\end{array}$ \\
\hline \multirow[t]{3}{*}{ 17p13/p53 } & SCC & $\begin{array}{c}83 \\
(\mathrm{NI}=14)\end{array}$ & $\begin{array}{c}76 \\
(\mathrm{NI}=20)\end{array}$ \\
\hline & $\mathrm{ADC}$ & $\begin{array}{c}75 \\
(\mathrm{NI}=33)\end{array}$ & $\begin{array}{c}75 \\
(\mathrm{NI}=33)\end{array}$ \\
\hline & $\mathrm{LC}$ & $\begin{array}{c}100 \\
(\mathrm{NI}=50)\end{array}$ & $\begin{array}{c}100 \\
(\mathrm{NI}=0)\end{array}$ \\
\hline \multirow[t]{3}{*}{ 18q21/DCC } & SCC & $\begin{array}{c}67 \\
(\mathrm{NI}=57)\end{array}$ & $\begin{array}{c}50 \\
(\mathrm{NI}=60)\end{array}$ \\
\hline & $\mathrm{ADC}$ & $\begin{array}{c}17 \\
(\mathrm{NI}=67)\end{array}$ & $\begin{array}{c}24 \\
(\mathrm{NI}=33)\end{array}$ \\
\hline & $\mathrm{LC}$ & $\begin{array}{c}100 \\
(\mathrm{NI}=0)\end{array}$ & NA \\
\hline \multirow[t]{3}{*}{$12 \mathrm{p} 12 / \mathrm{K}-$ ras-2 } & SCC & 0 & 20 \\
\hline & $\mathrm{ADC}$ & 28 & 33 \\
\hline & LC & 0 & 0 \\
\hline
\end{tabular}

SCC, squamous cell carcinoma; ADC, adenocarcinoma; LC, large cell undifferentiated carcinoma; NI, noninformative.
TABLE 3. Frequencies of LOH (\%) at Individual Chromosomal Loci and K-Ras-2 Mutation in the Recurrent (RC) and Nonrecurrent (NRC) Stage I NSCLC

\begin{tabular}{|c|c|c|c|}
\hline $\begin{array}{c}\text { Chromosomal } \\
\text { Locus/Gene Marker }\end{array}$ & Stage & $\begin{array}{c}\text { NRC } \\
(n=27)\end{array}$ & $\begin{array}{c}\mathrm{RC} \\
(n=12)\end{array}$ \\
\hline \multirow[t]{4}{*}{ 1p32/L-myc } & & 33 & 50 \\
\hline & $1 \mathrm{~A}$ & $(\mathrm{NI}=0)$ & $(\mathrm{NI}=0)$ \\
\hline & & 44 & 50 \\
\hline & 1B & $(\mathrm{NI}=0)$ & $(\mathrm{NI}=0)$ \\
\hline \multirow[t]{3}{*}{ 3p26/hOGG1 } & & 50 & 100 \\
\hline & $1 \mathrm{~A}$ & $(\mathrm{NI}=78)$ & $(\mathrm{NI}=75)$ \\
\hline & $1 \mathrm{~B}$ & $\begin{array}{c}20 \\
(\mathrm{NI}=44)\end{array}$ & $\begin{array}{c}50 \\
(\mathrm{NI}=50)\end{array}$ \\
\hline \multirow[t]{3}{*}{ 5q21/MCC/APC } & & 33 & 100 \\
\hline & $\mathrm{Al}$ & $(\mathrm{NI}=50)$ & $(\mathrm{NI}=75)$ \\
\hline & $1 \mathrm{~B}$ & $\begin{array}{c}80 \\
(\mathrm{NI}=44)\end{array}$ & $\begin{array}{c}50 \\
(\mathrm{NI}=50)\end{array}$ \\
\hline \multirow{3}{*}{$5 q 33.3 / c-f m s$} & & 33 & 67 \\
\hline & $1 \mathrm{~A}$ & $\begin{array}{c}(\mathrm{NI}=17) \\
40\end{array}$ & $\begin{array}{c}(\mathrm{NI}=75) \\
20\end{array}$ \\
\hline & 1B & $(\mathrm{NI}=44)$ & $(\mathrm{NI}=63)$ \\
\hline \multirow[t]{3}{*}{ 17p13/p53 } & 69 & 100 & \\
\hline & $1 \mathrm{~A}$ & $(\mathrm{NI}=28)$ & $(\mathrm{NI}=50)$ \\
\hline & 1B & $\begin{array}{c}71 \\
(\mathrm{NI}=22)\end{array}$ & $\begin{array}{c}71 \\
(\mathrm{NI}=13)\end{array}$ \\
\hline \multirow[t]{3}{*}{ 18q21/DCC } & & 50 & 0 \\
\hline & $1 \mathrm{~A}$ & $(\mathrm{NI}=67)$ & $(\mathrm{NI}=50)$ \\
\hline & $1 \mathrm{~B}$ & $\begin{array}{c}40 \\
(\mathrm{NI}=44)\end{array}$ & $\begin{array}{c}25 \\
(\mathrm{NI}=50)\end{array}$ \\
\hline \multirow{2}{*}{ 12p12/K-ras-2 } & $1 \mathrm{~A}$ & 22 & 0 \\
\hline & $1 \mathrm{~B}$ & 11 & 38 \\
\hline
\end{tabular}

NI, noninformative

(hOGG1) to $100 \%$ (L-myc). There was no statistical difference in the LOH profile between NRC and RC based on tumor histologic type. p53 was the most frequently affected gene in NRC (79\%) and RC (78\%) and in all histologic types (Fig. 1).

Even though squamous cell carcinoma and large cell undifferentiated carcinomas, but not adenocarcinomas, of NRC and RC groups showed tendency of frequent allelic losses in the region of APC/MCC gene located on the chromosome $5 q 21$, a very high

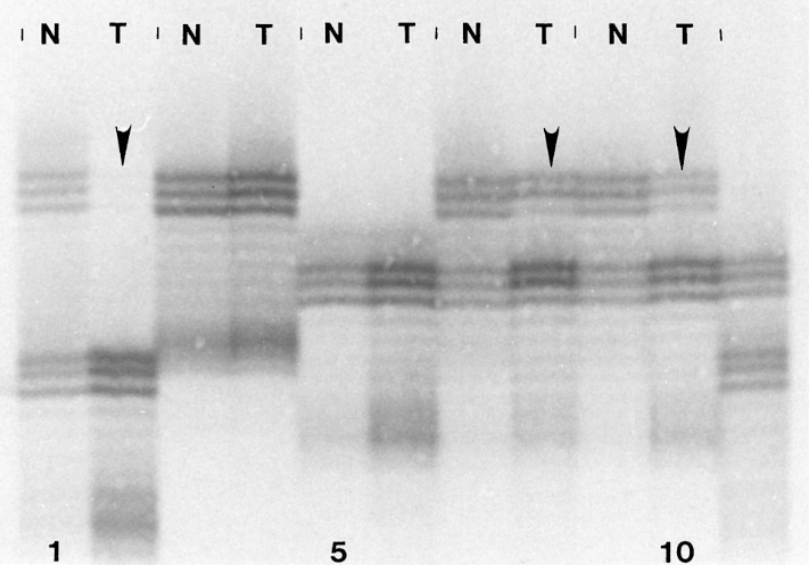

FIGURE 1. Detection of LOH at $17 \mathrm{p} 13$ using a microsatellite in intron 1 of the p53 gene. Normal (N) and corresponding tumors (T) are shown. LOH indicated by arrowhead in Lane Pairs 1 and 2; 7 and 8; and 9 and 10. Lanes 3 and 4 and 5 and 6 show noninformative patients. 
noninformative rate precluded definitive conclusions. Additional studies are needed to further elucidate the potential significance of this locus in the tumorigenesis of Stage I NSCLC and its potential prognostic value.

LOH in the DCC gene was more prevalent in the NRC group (45\%) compared with the RC (17\%), though this was not statistically significant $(P=.23$, $\chi^{2}$ test). Similar to APC, the gene also showed $\mathrm{LOH}$ in both informative LC carcinomas. The degree of informativeness was lowest for hOGG1 (36\%), making interpretation of results less reliable. There was, however, $\mathrm{LOH}$ in both (100\%) of the informative squamous cell carcinomas as compared with 4 of 10 (40\%) adenocarcinomas and 0 of $2(0 \%)$ LC carcinomas (Fig. 2).

L-myc showed LOH in $37 \%$ and $42 \%$ of NRC and $\mathrm{RC}$, tumors respectively. It was more common in squamous cell carcinoma (57\% and $60 \%$ ) and LC carcinoma $(50 \%$ and $100 \%)$ than in adenocarcinoma ( $28 \%$ and $17 \%)$. However, this was not statistically significant.

K-ras-2 mutations were all present in exon 1, codon 12 slightly more frequently in the RC (25\%) than in NRC (19\%) tumors; however, that difference was not statistically significant. Of RC tumors, 2 were adenocarcinoma, and 1 was squamous cell carcinoma showing a glycine to cysteine (GGT to TGT) mutation. All 5 cases of NRC tumors with $\mathrm{K}$-ras mutation were adenocarcinoma. Three cases showed a glycine to cysteine (GGT to TGT); one case, a glycine to alanine (GGT to GCT); and one case, a glycine to serine (GGT to AGT) mutation.

In summary, our study did not demonstrate a significant difference between the RC and NRC

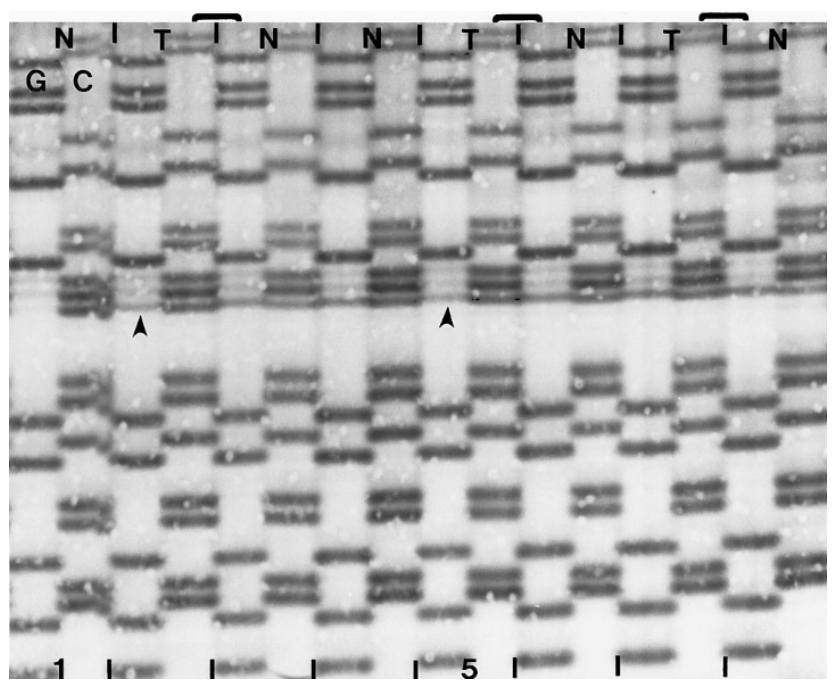

FIGURE 2. Detection of LOH using a single nucleotide polymorphism in exon 7 of the hOGG1 gene (3p26). Tumors (T) and normal (N) control tissue are shown. Lane 1, noninformative patient; Lanes 2 and 3, informative patient with LOH (arrowhead); Lane 4, informative patient with no LOH (not shown); Lanes 5 and 6, LOH; Lanes 7 and 8, no LOH.
Stage I NSCLC in respect to their histologic features, analyzed chromosomal loci, or fractional allelic loss.

\section{DISCUSSION}

Stage I NSCLC has a 5-year survival rate of 60$70 \%$ when treated with surgical resection alone. Prognostic factors to stratify Stage I patients into favorable and poor prognostic groups can potentially identify a group of patients that may be treated with surgery only, while improving survival with adjuvant therapy for patients with higher risk of recurrence.

We sought to address this issue by looking for alterations in a panel of genes aimed at recurrent and nonrecurrent Stage I NSCLC patients. We found that tumors in both the RC and NRC groups showed a degree and pattern of mutational change and $\mathrm{LOH}$ essentially similar to each other as highlighted by the FAL, calculated to be 0.52 and 0.46 in the two groups, respectively.

Specifically examining the various histopathologic features such as histologic type and pleural and angiolymphatic invasion, we found not a single feature that would distinguish the RC from NRC group. Similarly, none of the analyzed chromosomal loci could differentiate between RC and NRC. The lack of prognostic significance in this study may be due to the relatively small number of cases studied, but many other, often larger series also showed similar results $(12,23-26)$. However the approach of a single gene being of prognostic significance is probably too simplistic, and the interplay of different mutations at critical sites in known, and as yet undiscovered genes is likely to be more significant. We believe that using a panel approach will show a pattern of mutational change relatively specific to tumors of different sites and types that will be of value in better understanding of their pathways to carcinogenesis. It is with this concept in mind that we investigated for $\mathrm{LOH} /$ mutations using a combination of well and not-sowell studied genes in Stage I NSCLC. This panel can be expanded comprehensively to include other genes.

The use of intragenic microsatellites (MS) and single nucleotide polymorphisms (SNP) in all cases provided the advantage of examining the specific genes themselves, and not flanking regions of the chromosomes. Although $\mathrm{LOH}$ in any given gene does not provide direct evidence that it is critical to carcinogenesis in any given tumor type, it can still be useful as a marker for that chromosomal site, possibly for a nearby significant, hitherto unrecognized gene.

Turning our attention to the specific genes studied, p53 was the most commonly altered gene in 
both RC and NRC group, and indeed it is considered to be the most frequently mutated gene in human cancer overall (27). It functions as a critical gatekeeper by causing cell cycle arrest late in the G1 phase. This allows for repair of damaged DNA; or alternatively if repair mechanisms fail, p53 induces apoptosis (27). Mutation in one allele (assumed), and deletion in the other (seen as $\mathrm{LOH}$ ), would thus result in the failure of an important mechanism to prevent proliferation of abnormal cells. Mutations in p53 are thought to occur early in the development of lung cancer and have been found in squamous dysplasia and atypical adenomatous hyperplasia associated with NSCLC $(28,29)$. Point mutations and $\mathrm{LOH}$ are also present in 40 to $80 \%$ of invasive NSCLC $(11,12,30,31)$ and are found to be more frequent in tumors of squamous histology in one study (11), but with no relationship to histopathologic features in others (12). The relationship between p53 abnormalities and patient's prognosis is still controversial. Studies have found a statistically significant association between p53 mutations/LOH and poor prognosis in patients with Stage I NSCLC $(12,31)$, whereas others (11) have found p53 to be a prognostic factor in advanced (Stage III/IV) disease but not in earlier stages. Our study confirmed the previously published data (32), which showed that p53 cannot be used as a marker that would predict a high-risk for distant relapse in resected Stage I NSCLC. Our study shows LOH for p53 to be widespread in Stage I RC and NRC tumors, supporting the theory that p53 alterations may be an early event and alone may not be sufficient for carcinogenesis but create genetic instability and pave the way for other critical mutations to develop (11, 12, 33).

The second most frequently altered gene/chromosomal locus in RC and NRC in our study was an L-myc situated on chromosome 1p32. The L-myc oncogene has been reported in $27-38 \%$ of NSCLC and has been significantly associated with advanced disease and nodal metastases, though not with overall survival $(34,35)$. We were able to obtain a $100 \%$ informative rate for the L-myc gene using two intragenic markers-one MS and one SNPwith $41 \% \mathrm{LOH}$, but there was no statistically significant difference between RC and NRC. The frequent deletion of this site in these Stage I cancers suggests that it contains a significant tumor suppressor gene, involved not only in the progression of disease in advanced tumors, as suggested by others $(34,35)$, but also in the early stages of development of NSCLC. We found LOH in L-myc to be more frequent in squamous cell carcinomas and large cell undifferentiated carcinomas, similar to the findings of others $(34,35)$.

$\mathrm{LOH}$ in the APC gene or $5 \mathrm{q} 21$ region has been seen in 20 to $70 \%$ of NSCLC overall (22-24), and variably in 13 to $80 \%$ of Stage I/II patients (22-24). It has been more frequently found in squamous cell carcinoma as compared with adenocarcinoma (23, 24 ), which our study supports (80\% versus $50 \%$ ), whereas we additionally identified $\mathrm{LOH}$ in both of our large cell carcinomas informative for this gene. LOH in 5q21 has been associated with advanced disease and decreased survival $(22,24,30,36)$ in some studies. A very high noninformative rate precluded any significant conclusion about potential use of this marker in predicting the tumor recurrence. In addition, relatively small numbers of studied cases precluded meaningful statistical analyses of these subgroups, and larger series would be necessary.

The oncogene c-fms is located on chromosome 5q33.3 and belongs to the tyrosine kinase receptor family that straddle the cell membrane and transduce proliferation signals to the nucleus (37). Most studies looking at $5 \mathrm{q}$ deletions in lung cancer have concentrated on the APC/MCC cluster at 5q21, and little is known about the role of c-fms oncogene in lung carcinoma. In our study, $50 \%$ of RC adenocarcinoma and $31 \%$ of NRC adenocarcinoma manifest 5q33.3 LOH using a single highly informative (77\%) microsatellite marker. There was no difference between squamous cell carcinoma, and none of large cell undifferentiated carcinomas show $\mathrm{LOH}$ at this locus. Even though this was not statistically significant, this trend suggests that this chromosomal locus might play a potential role in predicting a recurrence in a subset of Stage I NSCLC. LOH at this site may be coincident with deletion of a nearby tumor suppressor gene, or alternatively, the c-fms oncogene may be the critical one at this site, as gene amplification has been known to give falsepositive $\mathrm{LOH}$ (38).

Deletion of chromosome $3 p$ has been found in $25-100 \%$ of NSCLC $(12,15,18,28,30,39)$ and is considered an early event present also in preneoplastic lesions $(28,30)$. It has been more frequently identified in squamous cell carcinoma than adenocarcinomas $(12,15,28,30)$. The prognostic significance of this locus is somewhat controversial. It has not been significantly associated with shorter survival in some studies $(12,25)$ but was a poor prognostic factor in adenocarcinomas in one (15). The gene hOGG1 located on 3p25-26 is responsible for repair of oxidative DNA damage produced by reactive oxygen species (40), and the latter is thought to play a role in lung carcinoma development. Mutations in this gene have been found in small cell lung cancer (41), and our laboratory has identified $\mathrm{LOH}$ for it in $61 \%$ of head and neck squamous cell carcinoma. In our study, squamous cell carcinomas showed more frequent $\mathrm{LOH}$ for this gene than other histological types, but there was no difference between RC and NRC groups. However, a very high 
noninformative rate reduced the number of cases available for interpretation and therefore limited our conclusions.

The ras oncogene codes for signal-transducing proteins present on the inner plasma membrane, and mutation results in continuous mitogenic stimulation of the cell. Mutations of K-ras-2 oncogene have been extensively studied in lung tumors and found to be associated with adenocarcinomas in our study and others $(9,10,26)$. The commonest mutation is TGT (cys), and although mutations in the ras gene overall have been found to be a poor prognostic factor for adenocarcinomas in some studies $(9,10)$, others have found specific mutations to be significant (GAT/asp and GTT/val) but not TGT (26). We found no association with tumor recurrence, possibly because most of the mutations identified were TGT.

LOH for the DCC gene located at $18 \mathrm{q} 21$ is common in colorectal cancer, and it has been recently described in lung cancer (42). In NSCLC, LOH at $18 \mathrm{q} 21$ has ranged from 14 to $48 \%$, associated with advanced disease in some studies $(43,44)$ but not others (24). Although the noninformative rate was relatively high, we noticed that the microsatellite marker at this chromosomal locus showed the lowest frequency of $\mathrm{LOH}$ in both RC and NRC groups without significant difference between the two groups. It is possible as suggested by the other authors that not DCC, but another putative tumor suppressor gene in this region, is important in lung carcinogenesis (45).

In summary, Stage I NSCLC show a high degree of mutational change similar to that of more advanced tumors and do not appear to represent biologically indolent tumors, but merely tumors that are fortuitously identified earlier in their development. However, our study did not show statistically significant correlation between genetic alterations and tumor recurrence. The pattern of mutational change for different histological subtypes varied, with squamous cell carcinoma showing an increased frequency of LOH for hOGG1 and L-myc, LC carcinomas for APC and DCC; and adenocarcinomas increased k-ras-2 mutations. The tumor suppressor gene hOGG1 on 3p25-26 shows frequent $\mathrm{LOH}(43 \%)$ and may be a critical gene in the pathogenesis of NSCLC. A subset of adenocarcinomas present in both RC and NRC groups, including well, moderately, and poorly differentiated tumors, showed no mutations/LOH for any of the genes studied, and may represent a distinct group from a molecular biology standpoint. Finally, we have found that the panel approach to investigating molecular alterations in tumors can yield significant patterns of mutational change and can be universally applied to various tumor types. The eventual goal is the recognition of one or, more likely, a combination of genes that are significant in the development of any given malignancy.

\section{REFERENCES}

1. Greenlee RT, Murray T, Bolden S, Wingo PA. Cancer statistics 2000. CA Cancer J Clin 2000;50:7-33.

2. Pelletier MP, Edwardes MD, Michel RP, Halwani F, Morin JE. Prognostic markers in resectable non-small cell lung cancer: a multivariate analysis. Can J Surg 2000;44:180-8.

3. Mountain CF. A new international staging system for lung cancer. Chest 1986;89:225S-33S.

4. Strauss GM, Kwiatkowski DJ, Harpole DH, Lynch TJ, Skarin AT, Sugarbaker DJ. Molecular and pathologic markers in stage I non-small-cell carcinoma of the lung. J Clin Oncol 1995;13:1265-79.

5. Flehinger BJ, Kimmel M, Melamed MR. The effect of surgical treatment on survival from early lung cancer: implications for screening. Chest 1992;101:1013-8.

6. Ichinose Y, Hara N, Ohta M, Yano T, Maeda K, Asoh H, et al. Is $\mathrm{T}$ factor of the TNM staging system a predominant prognostic factor in pathologic stage 1 non-small-cell lung cancer?-a multivariate prognostic factor analysis of 151 patients. J Thorac Cardiovasc Surg 1993;106:90-4.

7. Harpole DH Jr, Herndon DH II, Wolfe WG, Iglehart D, Marks JR. A prognostic model of recurrence and death in stage I non-small cell lung cancer utilizing presentation, histopathology, and oncoprotein expression. Cancer Res 1995;55: 51-6.

8. Harpole DH Jr, Richards WG, Herndon JE II, Sugarbaker DJ. Angiogenesis and molecular biologic substaging in patients with stage I non-small cell lung cancer. Annu Thorac Surg 1996;61:1470-6.

9. Slebos RJ, Kibbelaar RE, Dalesio O, Kooistra A, Stam J, Meijer $\mathrm{CJ}$, et al. K-ras oncogene activation as a prognostic marker in adenocarcinoma of the lung. N Engl J Med 1990;323:561-5.

10. Mitsudomi T, Steinberg SM, Oie HK, Mulshine JL, Phelps R, Viallet J, et al. Ras gene mutations in non-small cell lung cancers are associated with shortened survival irrespective of treatment intent. Cancer Res 1991;51:4999-5002.

11. Mitsudomi T, Oyama T, Kusano T, Osaki T, Nakanishi R, Shirakusa T. Mutation of the p53 gene as a predictor of poor prognosis in patients with non-small cell lung cancer. J Natl Cancer Inst 1993;85:2018-23.

12. Horio Y, Takahashi T, Kuroishi T, Hibi K, Suyama M, Niimi T, et al. Prognostic significance of p53 mutations and 3p deletions in primary resected non-small cell lung cancer. Cancer Res 1993;53:1-4.

13. Tomizawa Y, Adachi J, Kohno T, Hamada K, Saito R, Noguchi $\mathrm{M}$, et al. Prognostic significance of allelic imbalances on chromosome 9p in stage I non-small cell lung carcinoma. Clin Cancer Res 1999;5:1139-46.

14. Wistuba II, Behrens C, Virmani AK, Milchgrub S, Syed S, Lam S, et al. Allelic losses at chromosome 8p21-23 are early and frequent events in the pathogenesis of lung cancer. Cancer Res 1999;59:1973-9.

15. Mitsudomi T, Oyama T, Nishida K, Ogami A, Osaki T, Sugio $\mathrm{K}$, et al. Loss of heterozygosity at $3 \mathrm{p}$ in non-small cell lung cancer and its prognostic implication. Clin Cancer Res 1996; 2:1185-9.

16. Rodenhuis S, Slebos R, Boot A, Evers S, Mooi W, Wagenaar S, et al. Incidence and possible clinical significance of K-ras oncogene activation in adenocarcinoma of the human lung. Cancer Res 1988;48:5738-41.

17. Mitsudomi T, Oyama T, Nishida K, Ogami A, Osaki T, Nakanishi R, et al. p53 nuclear immunostaining and gene mutations in non-small cell lung cancer and their effect on patient survival. Annu Oncol 1995;10:9-13. 
18. Virmani AK, Fong KM, Kodagoda D, McIntire D, Hung J, Tonk V, et al. Allelotyping demonstrates common and distinct patterns of chromosomal loss in human lung cancer types. Genes Chromosomes Cancer 1998;21:308-19.

19. Zhou X, Kemp BL, Khuri FR, Liu D, Lee JJ, Wu W, et al. Prognostic implication of microsatellite alteration profiles in early-stage non-small cell lung cancer. Clin Can Res 2000;6: 559-65.

20. Fleming ID, Cooper JS, Henson DE, Hutter RP, Kennedy BJ, Murphy GP, et al., editors. AJCC Cancer Staging Manual. 5th ed. Philadelphia: Lippincott-Raven, 1997.

21. Vogelstein B, Fearon ER, Kern SE, Hamilton SR, Preisinger AC, Nakamura Y, et al. Allelotype of colorectal carcinomas. Science 1989;244:217-21.

22. Sanchez-Cespedes M, Rosell R, Pifarre A, Lopez-Cabrerizo MP, Barnadas A, Sanchez JJ, et al. Microsatellite alterations at $5 \mathrm{q} 21,11 \mathrm{p} 13$, and $11 \mathrm{p} 15.5$ do not predict survival in nonsmall cell lung cancer. Clin Cancer Res 1997;3:1229-35.

23. Sanz-Ortega J, Bryant B, Sanz-Esponera J, Asenjo J, Saez MC, Torres A, et al. $\mathrm{LOH}$ at the APC/MCC gene (5q21) is frequent in early stages of non-small cell lung cancer. Pathol Res Pract 1999;195:677-80.

24. Fong KM, Zimmerman PV, Smith PJ. Tumor progression and loss of heterozygosity at $5 q$ and $18 q$ in non-small cell lung cancer. Cancer Res 1995;55:220-3.

25. Geradts J, Fong KM, Zimmerman PV, Maynard R, Minna JD. Correlation of abnormal RB, p16 ${ }^{\text {ink4a }}$, and p53 expression with $3 p$ loss of heterozygosity, other genetic abnormalities, and clinical features in 103 primary non-small cell lung cancers. Clin Can Res 1999;5:791-800.

26. Gregorio LD, Manenti G, Incarbone M, Pilotti S, Pastorino U, Pierotti MA, et al. Prognostic value of loss of heterozygosity and kras2 mutations in lung adenocarcinoma. Int J Cancer 1998;79:269-72.

27. Levine AJ. p53, the cellular gatekeeper for growth and division. Cell 1997;88:323-31.

28. Kohno H, Hiroshima K, Toyozaki T, Fujisawa T, Ohwada H. p53 mutation and allelic loss of chromosome 3p, 9p of preneoplastic lesions in patients with non-small cell lung carcinoma. Cancer 1999;85:341-7.

29. Li ZH, Zheng J, Weiss LM, Shibata D. c-K-ras and p53 mutations occur very early in adenocarcinoma of the lung. Am J Pathol 1994;144:303-9.

30. Wistuba II, Behrens C, Milchgrub S, Bryant D, Hung J, Minna JD, et al. Sequential molecular abnormalities are involved in the multistage development of squamous cell lung carcinoma. Oncogene 1999;18:643-50.

31. Tomizawa Y, Kohno T, Fujita T, Kiyama M, Saito R, Noguchi $\mathrm{M}$, et al. Correlation between the status of the p53 gene and survival in patients with stage I non-small cell lung carcinoma. Oncogene 1999;18:1007-14.

32. Schiller JH, Adak S, Feins RH, Keller SM, Fry WA, Livingston $\mathrm{RB}$, et al. Lack of prognostic significance of p53 and K-ras mutations in primary resected non-small cell lung cancer on E4592: a laboratory ancillary study on an Eastern Cooperative Oncology Group prospective randomized trial of postoperative adjuvant therapy. J Clin Oncol 2001;19:448-57.

33. Lane DP. p53, guardian of the genome. Nature 1992;358: 15-6.

34. Fong KM, Kida Y, Zimmerman PV, Smith PJ. MYCL genotypes and loss of heterozygosity in non-small-cell lung cancer. Br J Cancer 1996;74:1975-8.

35. Gasparian AV, Laktionov KK, Belialova MS, Pirogova NA, Tatosyan AG, Zborovskaya IB. Allelic imbalance and instability of microsatellite loci on chromosome $1 p$ in human non-small-cell lung cancer. Br J Cancer 1998;77:1604-11.

36. Hosoe S, Ueno K, Shigedo Y, Tachibana I, Osaki T, Kumagai $\mathrm{T}$, et al. A frequent deletion of chromosome $5 \mathrm{q} 21$ in advanced small cell and non-small cell carcinoma of the lung. Cancer Res 1994;54:1787-90.

37. Andre C, Hampe A, Lachaume P, Martin E, Wang XP, Manus $\mathrm{V}$, et al. Sequence analysis of two genomic regions containing the KIT and the FMS receptor tyrosine kinase genes. Genomics 1997;39:216-26.

38. Nagai MA, Yamamoto L, Salaorni S, Pacheco MM, Brentani MM, Barbosa EM, et al. Detailed deletion mapping of chromosome segment 17q12-21 in sporadic breast tumors. Genes Chromosomes Cancer 1994;11:58-62.

39. Lu YJ, Dong XY, Shipley J, Zhang RG, Cheng SJ. Chromosome 3 imbalances are the most frequent aberration found in non-small cell lung carcinoma. Lung Cancer 1999;23:61-6.

40. Arai N, Morishita K, Shinmura K, Kohno T, Kim SR, Nohmi T, et al. Cloning of a human homolog of the yeast OGG1 gene that is involved in the repair of oxidative DNA damage. Oncogene 1997;14:2857-61.

41. Chevillard S, Radicella JP, Levalois C, Lebeau J, Poupon MF, Oudard S, et al. Mutations in OGG1, a gene involved in the repair of oxidative DNA damage, are found in human lung and kidney tumours. Oncogene 1998;16:3083-6.

42. Kohno T, Sato T, Takakura S, Takei K, Inoue K, Nishioka M, et al. Mutation and expression of the DCC gene in human lung cancer. Neoplasia 2000;2:300-5.

43. Shiseki M, Kohno T, Adachi J, Okazaki T, Otsuka T, Mizoguchi $\mathrm{H}$, et al. Comparative allelotype of early and advanced stage non-small cell lung carcinomas. Genes Chromosomes Cancer 1996;17:71-7.

44. Shiseki M, Kohno T, Nishikawa R, Sameshima Y, Mizoguchi H, Yokota J. Frequent allelic losses on chromosomes 2q, 18q, and 22q in advanced non-small cell lung carcinoma. Cancer Res 1994;54:5643-8.

45. Takei K, Kohno T, Hamada K, Takita J, Noguchi M, Matsuno $\mathrm{Y}$, et al. A novel tumor suppressor locus on chromosome 18q involved in the development of human lung cancer. Cancer Res 1998;58:3700-5. 